УДК 543.422:628.3

\title{
ПРЕВРАЩЕНИЯ ПОЛИСАХАРИДОВ И ЛИГНИНА В ДРЕВЕСИНЕ ПРИ ОЗОНИРОВАНИИ
}

\author{
(C) Н.А. Мамлеева ${ }^{* 1}$, С.А. Аутлов ${ }^{2}$ Н.Г. Базарнова ${ }^{2}$ В.В. Лунин ${ }^{1}$ \\ ${ }^{1}$ Московский государственный университет им. Ломоносова, химический \\ фракультет, Ленинские Горы, 1, стр.3, Москва, 119992 (Россия), \\ e-mail: mamleevana@bk.ru \\ ${ }^{2}$ Алтайский государственный университет, пр. Ленина, 61, Барнаул, 656049 \\ (Россия)
}

Озонирование рассматривается как метод предобработки растительной биомассы в процессах получения целлюлозы и моносахаридов. В работе представлены результаты изучения процесса поглощения озона древесиной осины с различным содержанием воды. Рассмотрено поэтапное превращение субстрата: исходная древесина - озонированная древесина - целлюлозосодержащий продукт озонирования - холоцеллюлоза - целлюлоза. Определены выходы озонированной древесины, водорастворимых продуктов озонирования древесины, выходы холоцеллюлозы и целлюлозы. Определен выход целлюлозосодержащего продукта озонирования и содержание остаточного лигнина в нем. Образцы холоцеллюлозы и целлюлозы изучены методом ИК-спектроскопии. Определены степень полимеризации и молекулярно-массовый состав целлюлозы из озонированной древесины.

Показано, что превращения древесины под воздействием озона сопровождаются деструкцией лигнина, гемицеллюлоз и части целлюлозы. Установлено, что физико-химические свойства целлюлозы, полученной из озонированной древесины, зависят от содержания воды. Варьирование содержания воды в исходном образце позволяет регулировать свойства целлюлозы из озонированной древесины.

Предполагается, что в процессе деструкции древесины участвуют как молекулярный озон, так и радикалы, образующиеся при взаимодействии озона с водой, присутствующей в клеточной структуре субстрата.

Ключевые слова: древесина, озонирование, лигнин, холоцеллюлоза, целлюлоза, степень полимеризации, молекулярно-массовый анализ, ИК-спектры поглощения.

\section{Введение}

Древесина является источником ряда ценных химических соединений, среди которых целлюлоза относится к наиболее востребованным продуктам конверсии биомассы. Уникальные химические, физические и физико-химические свойства обусловили широкое применение целлюлозы и продуктов на ее основе в самых различных областях - от космической техники до фармакологии. Поэтому поиск и разработка новых методов получения и изучение свойств целлюлозы относятся к приоритетным направлениям современной науки и технологии [1-4].

Озонирование является одним из способов обработки растительной биомассы. Озон рассматривают

Мамлеева Надежда Алексеевна - старший научный сотрудник, кандидат химических наук,

e-mail: mamleevana@bk.ru

Аутлов Станисла Артурович - кандидат химических наук, e-mail: autlov@mail.ru

Базарнова Наталья Григорьевна - декан химического факультета, заведующая кафедрой органической химии, доктор химических наук, профессор,

e-mail: bazarnova@chem.asu.ru

Лунин Валерий Васильевич - декан химического факультета, академик РАН, профессор, e-mail: vvlunin@kge.msu.ru как перспективный с экологической точки зрения реагент, так как он не образует токсичных продуктов превращения, кроме того, реакции озона идут при комнатной температуре и атмосферном давлении. Развитие озонных технологий и наметившаяся тенденция к снижению стоимости озона открывают новые возможности для его использования в области конверсии растительного сырья [4-10].

Как окислитель ароматических соединений озон нашел широкое применение в процессах дест-

\footnotetext{
* Автор, с которым следует вести переписку.
} 
рукции остаточного лигнина при отбелке бумажной массы [11-17]. Деструкцию лигнина наблюдали и при непосредственной обработке озоном растительного субстрата [4, 7, 18-21]. Исследовали озонирование различных субстратов (солома, кукурузные початки, маис, хвойная, лиственная древесина и др.) [4-10]. В работе [18] показана возможность достижения степени делигнификации 93\% при озонировании древесины осины. Методами ИК- и УФ-спектроскопии показано, что под действием озона происходит деструкция лигнина древесины, одновременно образуются растворимые в воде продукты окисления лигнина - ароматические карбонил- и карбоксилсодержащие соединения [18, 19].

Исследование озонирования растительных субстратов показало, что основные физико-химические характеристики процесса поглощения озона определяются условиями подготовки образца и параметрами озонирования [4, 18-22]. Важным условием делигнификации под действием озона является присутствие воды, причем эффективность процесса озонирования зависит от ее содержания в образце [4, 5, 9, 18-22]. Влияние воды на физико-химические свойства растительных субстратов и ее роль в процессе поглощения озона рассмотрены в работах $[4,5,19-23]$.

В данной работе продолжено исследование превращений древесины с различным содержанием воды под действием озона. Цель работы - рассмотреть поэтапное превращение субстрата: исходная древесина озонированная древесина - холоцеллюлоза - целлюлоза. Сопоставить свойства целлюлозы из древесины, озонированной при различном содержании воды.

\section{Экспериментальная часть}

Исследовали опилки древесины осины (Populus tremula) с размерами частиц от 0,315 до 0,63 мм с содержанием воды (moisture content - MC) от 8 до 160\% относительно массы абсолютно-сухой древесины (а.с.д.).

Озонирование образцов древесины массой 1,6 г с различным содержанием воды проводили в проточной системе в термостатированном $\left(25^{\circ} \mathrm{C}\right)$ реакторе с неподвижным слоем. Озоно-кислородную смесь с концентрацией озона 90 мг/л пропускали через реактор при скорости потока 4,4 л/ч. По окончании опыта генерацию озона прекращали, систему продували кислородом. Непрореагировавший озон поступал в каталитический патрон на выходе из системы, где разлагался. Концентрацию озона определяли спектрофотометрически. Критерием окончания реакции считали совпадение концентрации озона на входе и выходе из реактора. Из кинетических кривых зависимости концентрации озона на выходе из реактора определяли удельный расход озона $\mathrm{Q}_{\mathrm{r}}$ и общий расход озона $\mathrm{Q}_{\text {inlet }}$ (количество озона, прошедшего через реактор), как описано в $[18,21]$. Степень превращения озона $\alpha=\mathrm{Q}_{\mathrm{r}} / \mathrm{Q}_{\text {inlet. }}$ [21]. Опыты по изучению поглощения озона образцами древесины с определенным содержанием воды проводили по 4 раза. Это позволяло получить достаточное количество материала для последующего определения содержания остаточного лигнина и получения холоцеллюлозы и целлюлозы.

Содержание лигнина в исходном и озонированных образцах древесины определяли по методике [24]. Навеску древесины (1 г в пересчете на а.с.д.) обрабатывали 15 мл 72\% $\mathrm{H}_{2} \mathrm{SO}_{4}$ при комнатной температуре в течение 2,5 ч. Затем концентрацию кислоты доводили разбавлением водой до $8 \%$ и кипятили в колбе с обратным холодильником (1 ч). После охлаждения осадок отфильтровывали, промывали водой до нейтрального значения $\mathrm{pH}$ и сушили при $\mathrm{t}=103 \pm 2{ }^{\circ} \mathrm{C}$ до постоянной массы.

Холоцеллюлозу (ХЦ) выделяли из озонированных образцов (1 г) обработкой 10\% раствором надуксусной кислоты (50 мл) в течение 5-7 мин при комнатной температуре, помещали в термостат с температурой $90{ }^{\circ} \mathrm{C}$. Колбу выдерживали в бане в течение 20 мин до температуры $75{ }^{\circ} \mathrm{C}$ при периодическом перемешивании. Разбавляли содержимое 50 мл дистиллированной воды $\left(50^{\circ} \mathrm{C}\right)$ и отфильтровывали ХЦ на стеклянном фильтре (ПОР 160), промывали дистиллированной водой $\left(50^{\circ} \mathrm{C}\right)$ до отрицательной реакции с титанилсульфатом, затем смесью ацетон - этанол $(1: 1)$ при $20^{\circ} \mathrm{C}$. Образец высушивали на воздухе с последующим определением МС воздушно-сухой ХЦ [24].

Целлюлозу из ХЦ (1 г) получали гидролизом ХЦ 2\% водным раствором $\mathrm{HCl}$ (40 мл) при кипячении (3 ч). Остаток на фильтре отмывали горячей водой $\left(50{ }^{\circ} \mathrm{C}\right)$ и высушивали на воздухе с последующим определением МС воздушно-сухой целлюлозы [24].

Выход озонированной древесины (ОД) (Y1), определяли как отношение массы абсолютно-сухого озонированного образца ОД к массе исходной а.с.д. Образцы ОД промывали водой для удаления раство- 
римых соединений и высушивали. Выход Ү2 целлюлозосодержащего продукта (ЦП), а также выход холоцеллюлозы (ХЦ) (Y3) и целлюлозы (Y4) определяли как отношение массы абсолютно-сухой ХЦ или целлюлозы к массе исходной а.с.д.

Степень полимеризации растворов целлюлозы в кадоксене определяли вискозиметрически (капиллярный вискозиметр ВПЖ-3). Кривые молекулярно-массового распределения образцов целлюлозы получали методом турбидиметрического титрования растворов в кадоксене. В качестве осадителя использовали смесь этанол - вода $(7: 3)$. При построении кривых распределения определяли изменение оптической плотности раствора с учетом разбавления осадителем.

ИК-спектры поглощения образцов ХЦ и целлюлозы в виде таблеток $(0,1 \%$ образца в КВr) регистри-

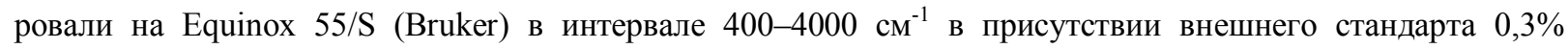
$\mathrm{K}_{4} \mathrm{Fe}(\mathrm{CN})_{6}$.

Электронные микрофотографии древесины получены на электронном микроскопе Camscan-2 (Japan).

\section{Обсуждение результатов}

На рисунке 1 приведены кинетические кривые зависимости удельного поглощения озона древесиной осины при различном содержании воды. Из рисунка видно, что увеличение содержания воды позволяет достигнуть более высоких значений удельного расхода озона $\mathrm{Q}_{\mathrm{r}}$. $\mathrm{Q}_{\mathrm{r} 3}>\mathrm{Q}_{\mathrm{r} 2}>\mathrm{Q}_{\mathrm{r} 1}$. Из начальных участков кинетических кривых видно, что при МС 55\% скорость поглощения озона превышает скорость поглощения озона образцом с содержанием воды $28 \%$, что соответствует точке насыщения волокна (ТНВ) древесины осины. При МС 55\% степень превращения озона $\alpha(20 \%)$ превышает значение $\alpha$, полученное при МС $28 \%$ или при МС 160\%, что предполагает более глубокую деструкцию субстрата в этих условиях (табл.).

Из образцов озонированной древесины, соответствующих окончанию процесса озонирования, были получены ХЦ и целлюлоза. В таблице приведены значения выходов озонированной древесины Ү1, целлюлозосодержащего продукта Ү2, холоцеллюлозы Y3 и целлюлозы Ү4, а также содержание остаточного лигнина (ЛГ) в целлюлозосодержащем продукте в зависимости от удельного расхода озона для различного содержания воды в древесине. Масса образцов после озонирования возрастает до 106\% при увеличении Qr

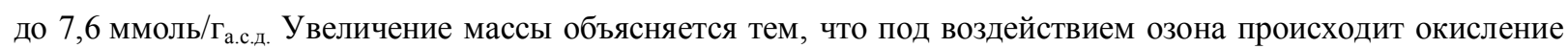
функциональных групп древесины, часть низкомолекулярных продуктов адсорбируется на поверхности ОД. После промывания озонированных образцов древесины содержание не растворимых в воде соединений (Y2) составило 63-66\% (рис. 2).

На рисунке 2 приведены значения выходов растворимых в воде продуктов озонирования. В области $\mathrm{Q}_{\mathrm{r}}=(2,5-7,6)$ ммоль/Га.с.д. выходы растворимых соединений составляют 37-42\% (табл., рис. 2), заметно снижаясь при низких значениях $\mathrm{Q}_{\mathrm{r}}$. В состав растворимых в воде продуктов входят различные кислоты (рН

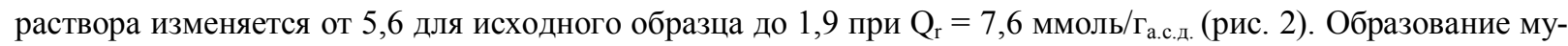
равьиной, глиоксалевой, щавелевой и других кислот при озонировании древесины отмечено в [6, 7, 9].
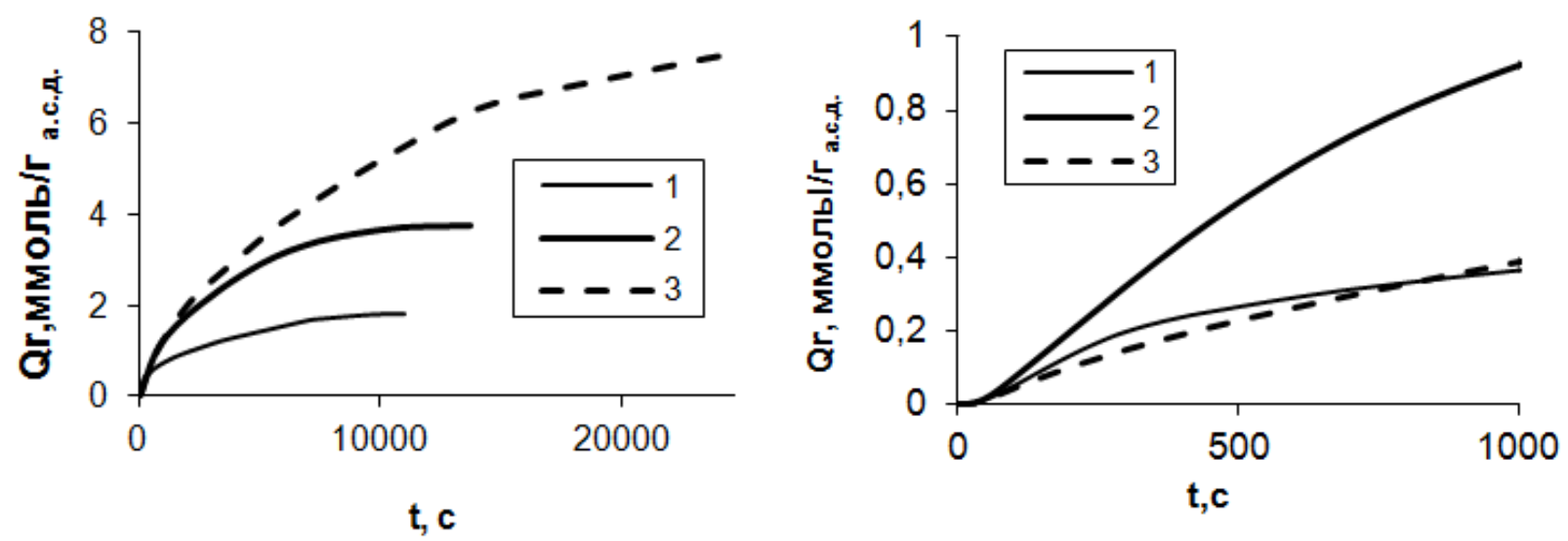

Рис. 1. Кинетические кривые зависимости удельного поглощения озона древесиной осины при различном содержании воды МС, \%: 28 (1), 55 (2), 160 (3) 
Выход озонированной древесины Ү1, целлюлозосодержащего продукта Ү2, холоцеллюлозы Ү3 и целлюлозы Y4, а также содержание остаточного лигнина (ЛГ) в целлюлозосодержащем продукте для различных значений удельного расхода и степени превращения озона при озонировании древесины с различным содержанием воды

\begin{tabular}{|c|c|c|c|c|c|c|c|c|}
\hline 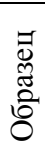 & $\begin{array}{c}\mathrm{MC}, \\
\%\end{array}$ & $\begin{array}{c}\mathrm{Qr}, \\
\text { ммоль/г } \\
\text { а.с.д. }\end{array}$ & $\begin{array}{c}\text { Степень } \\
\text { превращения } \\
\text { озона, } \alpha, \%\end{array}$ & $\begin{array}{c}\text { Содержание } \\
\text { лигнина, ЛГ, } \\
\%\end{array}$ & $\begin{array}{c}\text { Выход } \\
\text { озонирован- } \\
\text { ной древеси- } \\
\text { ны, Ү1, \% }\end{array}$ & $\begin{array}{c}\text { Выход целлю- } \\
\text { лозосодержа- } \\
\text { щего продук- } \\
\text { та, Y2, \% }\end{array}$ & $\begin{array}{c}\text { Выход } \\
\text { холоцеллю- } \\
\text { лозы, Y3, \% }\end{array}$ & $\begin{array}{c}\text { Выход } \\
\text { целлюлозы, } \\
\%\end{array}$ \\
\hline 1 & 8 & 0 & - & 25,3 & 100 & $98 \pm 1$ & $70 \pm 1$ & $42 \pm 1$ \\
\hline 2 & 8 & 0,8 & 3 & 21,5 & $99 \pm 1$ & $97 \pm 1$ & $70 \pm 1$ & $43 \pm 1$ \\
\hline 3 & 28 & 1,8 & 11 & 6,1 & $98 \pm 1$ & $83 \pm 1$ & $64 \pm 1$ & $43 \pm 1$ \\
\hline 4 & 55 & 3,8 & 20 & 3,8 & $102 \pm 1$ & $63 \pm 1$ & $54 \pm 1$ & $41 \pm 1$ \\
\hline 5 & 160 & 7,6 & 12 & 1,7 & $106 \pm 1$ & $66 \pm 1$ & $58 \pm 1$ & $46 \pm 1$ \\
\hline
\end{tabular}

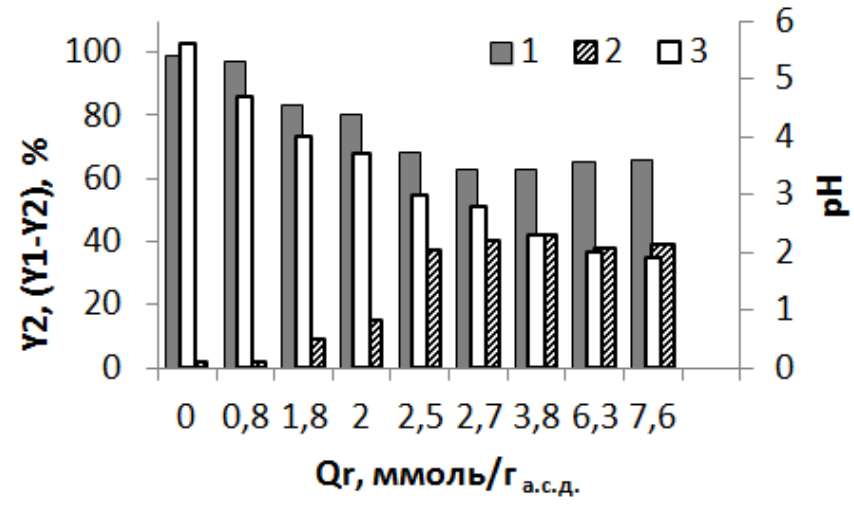

Рис. 2. Выход продуктов озонирования древесины осины в зависимости от удельного расхода озона. Y2 - после озонирования и промывания водой (1). (Y1-Y2) - растворимых продуктов озонирования (2). Значения рН контактных растворов (3)

Из электронных микрофотографий древесины рисунка 3 видно, что вследствие деструкции части материала древесины после озонирования ее волокнистая структура становится отчетливо выраженной (рис. 3А, Б).

При более высоком разрешении на микрофотографии на поверхности пор озонированной древесины видны тетраэдрические кристаллы размером до $1 \mu \mathrm{M}$, характерные для щавелевой кислоты, а также ее солей (рис. 3В). Образование щавелевой кислоты и оксалата кальция при озонировании лигноцеллюлозного материала отмечали в работе [15]. Присутствие этих соединений объясняет отмеченное увеличение выхода древесины после озонирования.

Из ЦП последовательно были получены ХЦ и целлюлоза. Данные таблицы показывают, что самый низкий выход Ү3 = 54\% у образца 4 , полученного озонированием образца древесины при МС 55\% с содержанием целлюлозы в ХЦ 76\%. С уве-

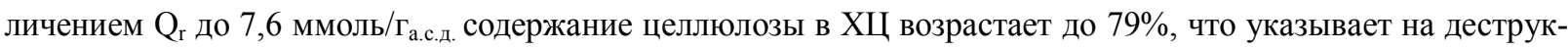
цию части гемицеллюлоз при озонировании. Отметим, что окисление гемицеллюлоз наблюдали и при озонировании других видов растительной биомассы $[5,6,18]$.

Изменение состава ХЦ из озонированной древесины при увеличении Q спектрами поглощения. В спектрах рисунка 4 видны полосы, характерные для углеводов. В области валентных С-Н колебаний спектры представляют собой суперпозицию полос поглощения, соответствующих валентным С-Н колебаниям целлюлозы, гемицеллюлоз и лигнина. Максимум при 2927 см $^{-1}$ в спектре 1 рисунка 4 можно отнести к валентным С-Н колебаниям метильных и метиленовых групп лигнина и гемицеллюлоз типа ксилана. Одновременно видна полоса $2851 \mathrm{~cm}^{-1}$, относящаяся к лигнину.
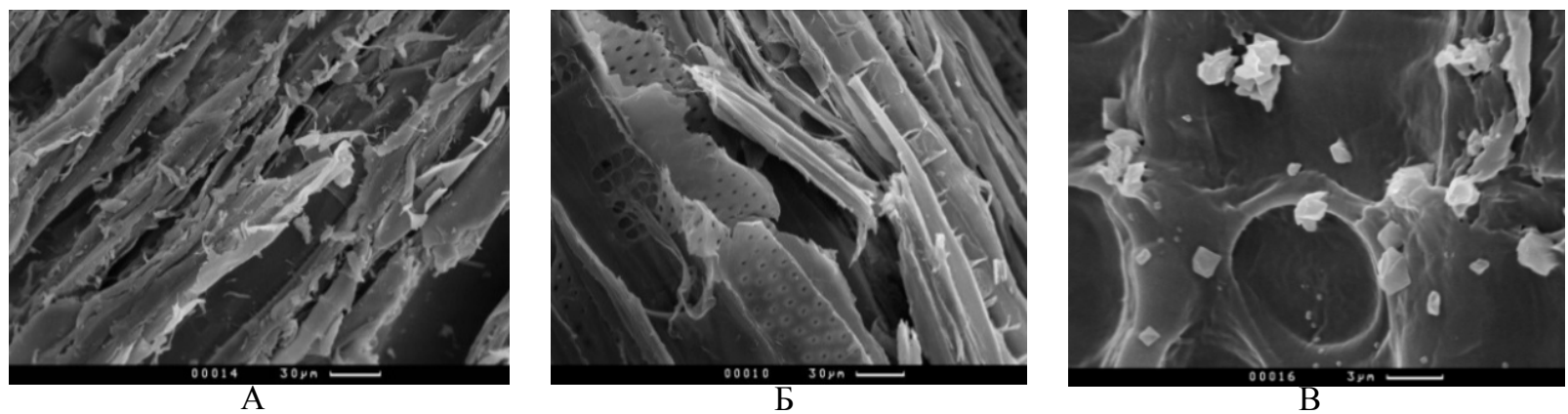

Рис.3. Электронные микрофотографии исходной (А) и озонированной древесины (Б, В). $Q_{r}$, ммоль $/ \Gamma$ а.с.д.: (A) $-0 ;($ Б, B $)-7,6$. 
Основное отличие ИК-спектров ХЦ из озонированной древесины состоит в заметном увеличении оптической плотности полосы $2900 \mathrm{~cm}^{-1} \mathrm{C}-\mathrm{H}$ колебаний метиленовых и метиновых групп целлюлозы [24]. В спектрах 2 и 3 видны также плечи при 2850 и $2940 \mathrm{~cm}^{-1}$, которые можно отнести к $\mathrm{C}-\mathrm{H}$ колебаниям в $\mathrm{OCH}_{3}$ группах $[3,24]$, присутствующим в гемицеллюлозе или ЛГ.

С увеличением $\mathrm{Q}_{\mathrm{r}}$ в спектре увеличивается интенсивность поглощения при $1429,1059,898 \mathrm{~cm}^{-1}$, что также указывает на увеличение доли целлюлозы в составе холоцеллюлозы, выделенной из озонированной древесины. Наблюдается смещение полосы валентных ОН- колебаний от 3440 до $3430 \mathrm{~cm}^{-1}$, свидетельствующее об образовании более прочных водородных связей, сопровождающих удаление части аморфной фазы - лигнина и гемицеллюлоз. Этот результат согласуется с выводом о возрастании доли целлюлозы в ХЦ из озонированной древесины.

Из ХЦ были выделены целлюлозы. Выход целлюлозы относительно а.с.д. сопоставим с ее содержанием в исходной древесине и составляет $41-46 \%$ (табл.).

ИК-спектры поглощения целлюлозы из озонированной древесины приведены на рисунке 5 . В целом все спектры идентичны и характеризуются полосами $\left(\right.$ см $\left.^{-1}\right)$ 898, 1059, 1110, 1159, 1248, 1372, 1429, 2900, типичными для целлюлозы $[2,3,25]$. Широкая полоса поглощения в области $3700-3100 \mathrm{~cm}^{-1}$ связана с валентными колебаниями ОН-групп, вовлеченными в образование водородных связей.

Полоса $2900 \mathrm{~cm}^{-1}$ относится к С-Н валентным колебаниям, полосы поглощения 1429 и $898 \mathrm{~cm}^{-1}$ относятся соответственно к ножничным колебаниям метиленовой группы и атома $\mathrm{C}^{1}$ и колебаниям четырех окружающих его атомов в $\beta$-гликозидных структурах $[2,3]$.

Соотношение $\mathrm{D}_{1429} / \mathrm{D}_{898}$ используют для оценки степени кристалличности целлюлозы, так как полосу $1429 \mathrm{~cm}^{-1}$ считают полосой «кристалличности», а полосу $898 \mathrm{~cm}^{-1}$ - полосой «аморфности» [2, 3]. Для спектров 1 , 2 и 3 соотношение $\mathrm{D}_{1429} / \mathrm{D}_{898}$ составило 2,31, 2,12 и 2,37 соответственно. Спектр 2 характеризуется наиболее низким значением параметра $\mathrm{D}_{1429} / \mathrm{D}_{898}$, что указывает на возрастание аморфности данного образца целлюлозы. Снизилась интенсивность и расширилась полоса при $3376 \mathrm{~cm}^{-1}$, что свидетельствует о структурной неоднородности образца.

На рисунке 6 приведены дифференциальные кривые осаждения целлюлозы смесью этанол - вода из растворов в кадоксене. Целлюлоза из исходной древесины полидисперсна; на дифференциальных кривых наблюдаются два максимума (рис. 6, кривая 1).

Кривые осаждения целлюлозы, полученной из озонированной древесины, смещены в сторону увеличения объемной доли осадителя, что указывает на деструкцию целлюлозы. При $\mathrm{Q}_{\mathrm{r}}=3,8$ ммоль $/ \Gamma_{\text {a.с.д. }}$ кривая распределения характеризуется наиболее широким диапазоном молекулярных масс;

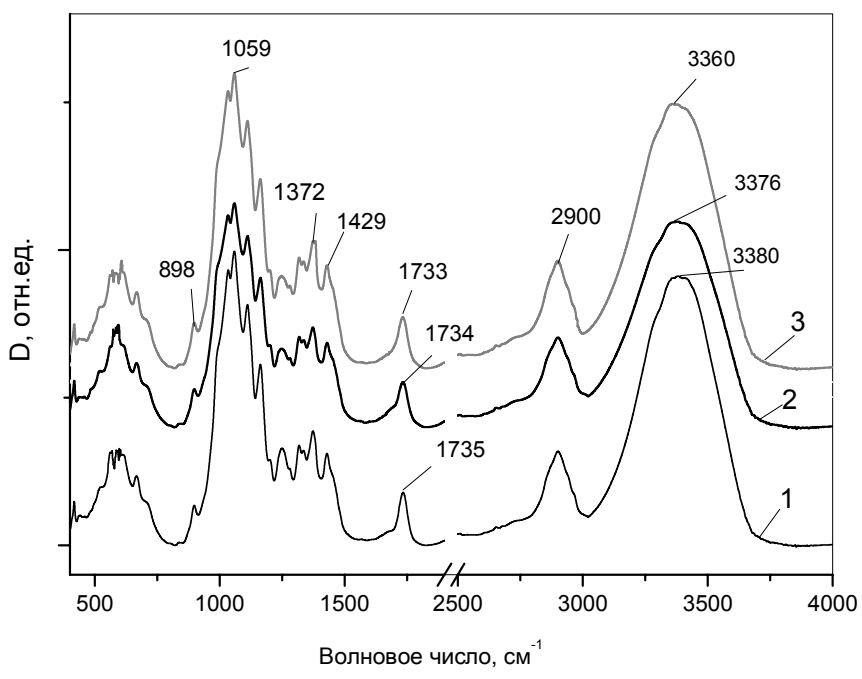

Рис.5. ИК-спектры поглощения целлюлозы.

$\mathrm{Q}_{\mathrm{r}}$, ммоль $/ \Gamma_{\text {а.с.д. }}: 0$ (1), 3,8 (2), 7,6 (3) 


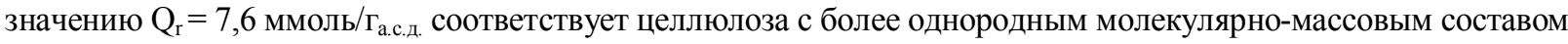
(рис. 6, кривая 3).

Среднее значение степени полимеризации (СП) целлюлозы из исходной древесины составляет 700.

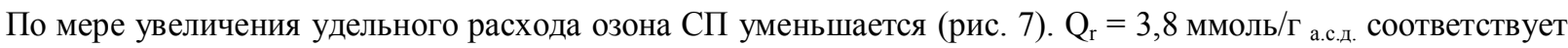
целлюлоза с СП 280. Целлюлоза из древесины, озонированной при МС 160\%, характеризуется значением СП 220. Деструкция целлюлозы наблюдается при высоких расходах озона, достигаемых при длительном озонировании (рис. 1, 7). Это согласуется с данными работы [10], где наблюдали деполимеризацию целлюлозы лиственной древесины после продолжительного озонирования.

На рисунке 7 приведена кривая зависимости содержания остаточного ЛГ от расхода озона. Из сопоставления кривых 1 и 2 рисунка 7 видно, что деструкция ЛГ происходит при значительно более низких значениях расхода озона, а на начальном этапе озонирования является преобладающим процессом. Авторы работ $[8,9]$ считают, что при озонировании растительной биомассы лигнин селективно окисляется озоном, полагая деструкцию углеводной части биомассы пренебрежимо малой. Наши данные свидетельствуют о том, что под действием озона разрушается структура субстрата в целом. Например, озонирование при МС $55 \%$ вызывает снижение выходов озонированной древесины, холоцеллюлозы и целлюлозы. В этих условиях лигнин разрушился не полностью, его содержание составило 3,8\%. Скорость окисления лигнина на несколько порядков превышает скорость окисления углеводов [4], поэтому полученный результат объясняется тем, что процесс окисления субстрата озоном контролируется диффузией.

Глубина деструкции древесины при обработке озоном зависит от содержания воды, и МC $55-60 \%$ наиболее благоприятно для реакций озона с субстратом [22]. Реакция идет быстрее, достигается наибольшая степень превращения озона, что соответствует наиболее глубокой деструкции древесины; выход озонированной древесины уменьшается, и соответственно именно в этих условиях возрастает выход растворимых в воде соединений. Озонирование при более высоких МС сопровождается «нецелевым» расходом части озона на окисление продуктов озонирования, растворенных в воде.

Как видно, наиболее заметный эффект воздействия $\mathrm{O}_{3}$ на древесину наблюдается при значении МС, превышающем точку насыщения волокна. Этот факт согласуется с выводом ряда авторов $[4,5,9,21,22]$ о необходимости некоторого избытка воды относительно ТНВ исследуемого субстрата, позволяющего достигнуть заметного эффекта воздействия озона.

Взаимодействие озона с древесиной протекает в аморфных областях лигноуглеводного комплекса (ЛУК), состоящего из гемицеллюлоз и ароматических структур лигнина. Будучи наиболее легко окисляемой частью структурной организации, доступная реагенту ароматика разрушается в первую очередь, и этот процесс неизбежно приводит к превращениям ковалентно связанных с лигнином углеводов ЛУК. Целлюлоза также частично подвергается деструкции.

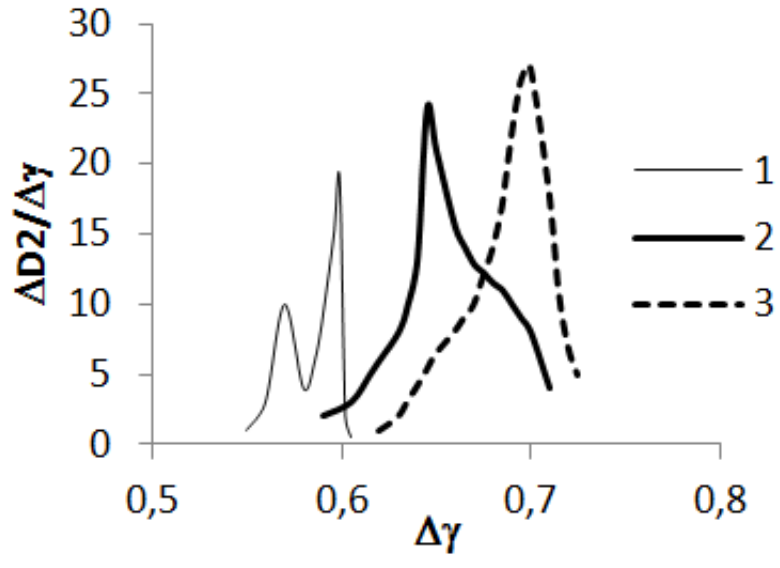

Рис. 6. Дифференциальные кривые осаждения целлюлозы из растворов в кадоксене смесью этанол - вода: Qr , ммоль/Г а.с.д.: 0 (1), 3,8 (2), 7,6 (3)

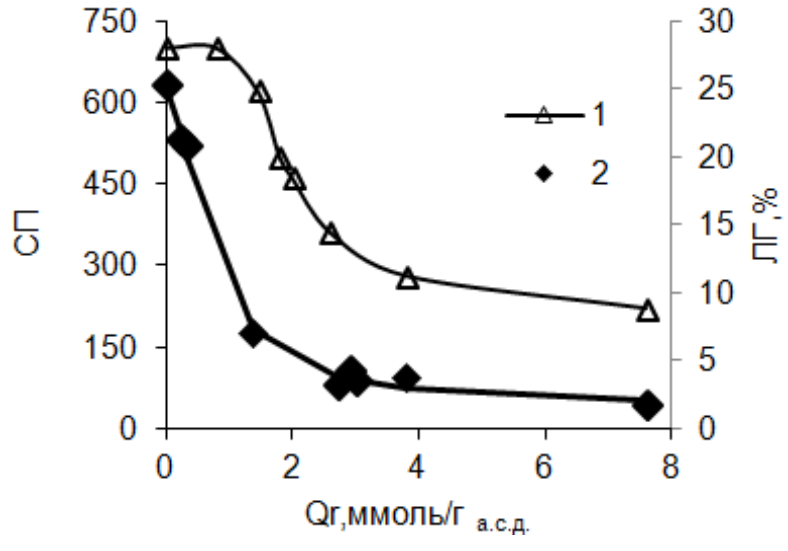

Рис. 7. Зависимость средней степени полимеризации целлюлозы (СП) и содержания остаточного лигнина в целлюлозосодержащем материале (2) от удельного расхода озона 
Изучение взаимодействия озона с древесиной показало, что в реакциях с древесиной принимает участие, главным образом, озон, растворенный в воде, присутствующей в клеточной структуре древесины [18]. Взаимодействие $\mathrm{O}_{3}$ с молекулами воды приводит к генерации $\mathrm{OH}^{\bullet}$ радикалов и супероксид-радикалов $\mathrm{O}_{2}^{\bullet-}$ [26]. Деструкция ароматических структур, согласно [12], происходит по механизму электрофильного присоединения молекулы $\mathrm{O}_{3}$ к ароматической системе. Возможен и другой механизм, предполагающий основным направлением реакции образование феноксильных радикалов с последующим раскрытием ароматического кольца и образованием непредельных кислот, альдегидов, перекисных соединений [11]. Отмечают [15, 27], что лигнин подвергается деструкции под действием электрофильных частиц: $\mathrm{O}_{3}$ и $\mathrm{OH}^{\bullet}$ радикалов.

Действие $\mathrm{O}_{3}$ и $\mathrm{OH}^{\bullet}$ радикалов на углеводы состоит в разрыве гликозидных связей и окислении спиртовых групп, что приводит к уменьшению степени полимеризации и образованию карбонильных и карбоксильных соединений [13, 14, 27-29]. В работе [15] отмечено, что за превращения углеводов при озонировании целлюлозосодержащих материалов ответственны $\mathrm{O}_{2}^{\bullet-}$ радикалы. Нельзя исключить и предлагаемое авторами $[17,28]$ наличие взаимосвязи между процессами деструкции ароматических систем и углеводов за счет промежуточных продуктов окисления лигнина (феноксильные радикалы, ОН радикалы, озониды).

Под действием активных частиц при озонировании древесины происходит деструкция лигнина и полисахаридов in situ. Озонирование древесины при МC 55\% соответствует наибольшей степени превращения озона. В этих условиях из древесины был получен целлюлозосодержащий материал с содержанием лигнина 3,8\% и содержанием целлюлозы 65\%. Целлюлоза из озонированной древесины с содержанием воды 55\% отличается от целлюлозы, полученной при более высоком расходе озона, рядом свойств: степенью полимеризации, менее однородным молекулярно-массовым составом и более аморфной структурой.

\section{Bbыводbl}

1. Озонирование древесины вызывает окислительную деструкцию лигнина и полисахаридов, которая усиливается с увеличением удельного расхода озона.

2. Выход целлюлозы, средняя степень полимеризации, молекулярно-массовые характеристики и надмолекулярная структура зависят от содержания воды в древесине, подвергнутой озонированию. Варьирование содержания воды позволяет регулировать свойства целлюлозы из озонированной древесины.

\section{Список литературы}

1. Hubbe M.A., Rojas O.J., Lucia L.A., Sain M. Cellulosic nanocomposites: a review // Bioresources. 2008. Vol. 3, N3. Pp. 929-980.

2. Ciolacu D., Ciolacu F., Popa V. Amorphous cellulose - structure and characterization // Cellulose Chem. Technol. 2011. Vol. 5, N1-2. Pp. 13-21.

3. Базарнова Н.Г., Карпова Е.В., Катраков И.Б., Маркин В.И., Микушина И.В., Ольхов Ю.А., Худенко С.В. Методы исследования древесины и ее производных. Барнаул, 2002. 160 с.

4. Travaini,R. Martín-Juárez, J., Lorenzo-Hernando, A., Bolado-Rodriges S. Ozonolysis: An advantageous pretreatment for lignocellulosic biomass revisited // Bioresource Technology. 2016. Vol. 199. Pp. 2-12.

5. $\quad$ Li C., Wang L., Chen Z., Li Y., Wang R., Luo X., Cai G., Li Y., Yu Q., Lu J. Ozonolysis pretreatment of maize stover: the interactive effect of particle size and moisture content on ozonolysis process // Bioresource Technol. 2015. Vol. 183. Pp. 240-247.

6. Yu Z., Jameel H., Chang H.-M., Park S. The effect of delignification of forest biomass on enzymatic hydrolysis // Bioresource Technol. 2011. Vol. 102. Pp. 9083-9089.

7. Garcia-Cubero M.T., Palacín L.G., Gonzales-Benito G., Bolado S., Lucas S. An analysis of lignin removal in fixed bed reactor by reaction of cereal straws with ozone // Bioresource Technol. 2012. Vol. 107. Pp. 229-234.

8. Sugimoto T., Magara K., Hosoya S., Oosawa S., Shimoda T., Nishibori K. Ozone pretreatment of lignocellulosic materials for ethanol production: Improvement of enzymatic susceptibility of softwood // Holzforschung. 2009. Vol. 63, N5. Pp. 537-543.

9. Бенько Е.М., Манисова О.Р., Лунин В.В. Влияние озонирования на реакционную способность лигноцеллюлозных субстратов в процессах ферментативного гидролиза в сахара // Журнал физической химии. 2013. T. 87, №7. C. 1131-1137.

10. Schuerch C. Ozonation of cellulose and wood // J. Polym. Sci. Part C. 1963. N2. Pp. 79-95.

11. Разумовский С.Д., Заиков Г.Е. Озон и его реакции с органическими соединениями (кинетика и механизм). М.,1974. 322 c.

12. Bailey P.S. Ozonation in Organic Chemistry. Vol. 2. Nonolefinic compounds. New York, 1982. Pp. 31-37.

13. Simoes R.M.S., Castro J.A.M.E. Ozone delignification of pine and eucalyptus kraft pulps. 2. Selectivity // Industrial \& Engineering Chemistry Research. 1999. Vol. 38, N12. Pp. 4608-4614. 
14. Brochier B., Kuligowski C., Voiron S., Petit-Conil M. Overview of the use of ozone in the pulp and paper industry // Ozone news. 2006. Vol. 34, N6. Pp. 21-28.

15. Roncero M.B., Colom J.F., Vidal T. Cellulose protection during ozone treatments of oxygen delignified Eucaliptus kraft pulp // Carbohydrate Polymers. 2003. Vol. 51, N4. Pp. 411-422.

16. Rounsaville J., Rice R.G. Evolution Of Ozone For Bleaching Of Paper Pulps // Ozone: Science \& Engineering. 1997. Vol. 18. Pp. 549-566.

17. Донцов А.Г. Избирательность делигнификации лиственной целлюлозы озоном : автореф. дисс. .... канд. хим. наук. Архангельск, 2001. 20 с.

18. Mamleeva N.A., Autlov S.A., Bazarnova N.G., Lunin V.V. Delignification of softwood by ozonation // Pure Appl. Chem. 2009. Vol. 81, N11. Pp. 2081-2091.

19. Мамлеева Н.А., Аутлов С.А., Фионов А.В., Базарнова Н.Г, Лунин В.В. Окислительная деструкция лигнина при озонировании древесины // Журнал физической химии. 2009. Т. 83, №5. С. 860-868.

20. Mamleeva N.A., Abrosimova G.E., Kharlanov A.N., Lunin V.V. Transformation of Wood during Ozonization in the Presence of Hydrogen Peroxide // Russian Journal of Physical Chemistry A. 2013. Vol. 87, N7. Pp. 1102-1107.

21. Мамлеева Н.А., Харланов А.Н., Лунин В.В. Делигнификация лиственной древесины под воздействием пероксида водорода и озона // Журнал физической химии. 2013. Т. 87, №1. С. 32-39.

22. Мамлеева Н.А., Аутлов С.А., Харланов А.Н., Базарнова Н.Г., Лунин В.В. ИК-спектры целлюлозы из озонированой древесины // Журнал физической химии. 2015. Т. 89, №8. С. 1298-1304.

23. Engelund E.T., Thygesen L.G., Svensson S., Hill C.A.S. A critical discussion of the physics of wood - water interactions // Wood Sci. Technol. 2013. Vol. 47. Pp. 141-161.

24. Оболенская А.В., Ельницкая 3.П., Леонович А.А. Лабораторные работы по химии древесины и целлюлозы. M., $1991.320 \mathrm{c}$.

25. Marchessault R.H. Application of infrared spectroscopy to cellulose and wood polysaccharides // Pure Appl. Chem. 1962. Vol. 5, N1-2. Pp. 107-129.

26. Staehelin J., Hoigné J. Decomposition of ozone in water: rate of initiation by hydroxide ions and hydrogen peroxide // Environ. Science Technol. 1982. Vol. 16, N12. Pp. 666-681.

27. Дёмин В.А., Шерешовец В.В., Монаков Ю.Б. Реакционная способность лигнина и проблемы его окислительной деструкции перокси-реагентами // Успехи химии. 1999. Т. 68, №11. С. 1029-1050.

28. Olkkonen C., Tylli Y., Forsskåhl I., Fuhrmann A., Hausalo T., Tamminen T., Hortling B., Janson J. Degradation of Model Compounds for Cellulose and Lignocellulosic Pulp during Ozonation in Aquous Solution // Holzforschung. 2000. Vol. 54. Pp. 397-406.

29. Lemeune S., Jameel H., Chang H.-M., Kadla J.F. Effect of ozone and chlorine dioxide on the chemical properties of cellulose fibers // J. Applied Polymer Science. 2004. Vol. 93, N3. Pp. 1219-1223.

Поступило в редакиию 30 ноября 2015 г.

После переработки 25 декабря 2015 г. 
Mamleeva N.A..$^{*}$, Autlov S.A. ${ }^{2}$, Bazarnova N.G. ${ }^{2}$, Lunin $V . .^{l}{ }^{l}$ DEGRADATION OF POLYSACCHARIDES AND LIGNIN IN WOOD OZONATION

${ }^{I}$ Moscow State University, Chemistry Department, Leninskie Gory, 1, bld. 3, Moscow, 119992 (Russia), e-mail: mamleevana@bk.ru

${ }^{2}$ Altai State University, Lenin pr., 61, Barnaul, 656049 (Russia)

Ozonation is a method of vegetable raw substrates pretreatment in relation to cellulose as well as monosaccharides processing. It was investigated the process of ozone consumption by wood of various water content. The data on lignin and polysaccharides transformations in aspen wood ozonation are presented in the paper. It was considered a gradual transformation of the substrate: wood ozonated wood - cellulose-containing product - holocellulose - cellulose. Yields of ozonated wood, cellulose-containing product, water soluble ozonaton products, holocellulose, and cellulose were determined. The lignin content in the cellulose-containing product was determined. Both holocellulose and cellulose samples were studied by IR spectroscopy method. The degree of polymerization, and molecular mass distribution of cellulose obtained from ozonated wood were determined.

It is shown that destruction of wood by ozone impact is accompanied by lignin, hemicelluloses, and cellulose degradation. It is found that physicochemical properties of cellulose obtained from ozonated wood can be regulated by the variation of the initial water content of the substrate. Wood destruction is due to reactions of molecular ozone as well as radical species which have been generated by ozone reactions with water presenting in the substrate structure.

Keywords: wood, ozonation, lignin, holocellulose, cellulose, degree of polymerization, molecular mass analysis, IR absorption spectra.

\section{References}

1. Hubbe M.A., Rojas O.J., Lucia L.A., Sain M. Bioresources. 2008, vol. 3, no. 3, pp. 929-980.

2. Ciolacu D., Ciolacu F., Popa V. Cellulose Chem. Technol., 2011, vol. 5, no. 1-2, pp. 13-21.

3. Bazarnova N.G., Karpova E.V., Katrakov I.B., Markin V.I., Mikushina I.V., Olkhov Iu.A., Khudenko S.V. Metody issledovaniia drevesiny i ee proizvodnykh. [Research Methods of wood and its derivatives]. Barnaul, 2002, 160 p. (in Russ.).

4. Travaini,R. Martín-Juárez, J., Lorenzo-Hernando, A., Bolado-Rodriges S. Bioresource Technology, 2016, vol. 199, pp. $2-12$.

5. $\quad$ Li C., Wang L., Chen Z., Li Y., Wang R., Luo X., Cai G., Li Y., Yu Q., Lu J. Bioresour. Technol., 2015, vol. 183, pp. 240-247.

6. $\quad$ Yu Z., Jameel H., Chang H.-M., Park S. Bioresource Technol., 2011, vol. 102, pp. 9083-9089.

7. Garcia-Cubero M.T., Palacín L.G., Gonzales-Benito G., Bolado S., Lucas S. Bioresource Technol., 2012, vol. 107, pp. 229-234.

8. Sugimoto T., Magara K., Hosoya S., Oosawa S., Shimoda T., Nishibori K. Holzforschung, 2009, vol. 63, N5, pp. 537-543.

9. Ben'ko E.M., Manisova O.R., Lunin V.V. Zhurnal fizicheskoi khimii, 2013, vol. 87, no. 7, pp. 1131-1137. (in Russ.).

10. Schuerch C. J. Polym. Sci. Part C, 1963, no. 2, pp. 79-95.

11. Razumovskii S.D., Zaikov G.E. Ozon i ego reaktsii s organicheskimi soedineniiami (kinetika i mekhanizm). [Ozone and its reaction with organic compounds (kinetics and mechanism)]. Moscow, 1974, 322 p. (in Russ.).

12. Bailey P.S. Ozonation in Organic Chemistry, vol. 2. Nonolefinic compounds, New York, 1982, pp. 31-37.

13. Simoes R.M.S., Castro J.A.M.E. Industrial \& Engineering Chemistry Research, 1999, vol. 38, no. 12, pp. $4608-4614$.

14. Brochier B., Kuligowski C., Voiron S., Petit-Conil M. Ozone news, 2006, vol. 34, no. 6, pp. 21-28.

15. Roncero M.B., Colom J.F., Vidal T. Carbohydrate Polymers, 2003, vol. 51, no. 4, pp. 411-422.

16. Rounsaville J., Rice R.G. Ozone: Science \& Engineering, 1997, vol. 18, pp. 549-566.

17. Dontsov A.G. Izbiratel'nost' delignifikatsii listvennoi tselliulozy ozonom : avtoref. diss. ... kand. khim. nauk. [The selectivity of the delignification of hardwood pulp with ozone: the dissertation author's Candidate of Chemical Science]. Arkhangelsk, 2001, 20 p. (in Russ.).

18. Mamleeva N.A., Autlov S.A., Bazarnova N.G., Lunin V.V. Pure Appl. Chem., 2009, vol. 81, no. 11, pp. $2081-2091$.

19. Mamleeva N.A., Autlov S.A., Fionov A.V., Bazarnova N.G, Lunin V.V. Zhurnal fizicheskoi khimii, 2009, vol. 83, no. 5, pp. 860-868. (in Russ.).

20. Mamleeva, N.A., Abrosimova, G. E., Kharlanov, A. N., Lunin V.V. Russian Journal of Physical Chemistry A, 2013, vol. 87, no. 7, pp. 1102-1107.

21. Mamleeva N.A., Kharlanov A.N., Lunin V.V. Zhurnal fizicheskoi khimii, 2013, vol. 87, no. 1, pp. 32-39. (in Russ.).

22. Mamleeva N.A., Autlov S.A., Kharlanov A.N., Bazarnova N.G., Lunin V.V. Zhurnal fizicheskoi khimii, 2015, vol. 89, no. 8, pp. 1298-1304. (in Russ.).

23. Engelund E.T., Thygesen L.G., Svensson S., Hill C.A.S. Wood Sci. Technol., 2013, vol. 47, pp. 141-161.

24. Obolenskaia A.V., El'nitskaia Z.P., Leonovich A.A. Laboratornye raboty po khimii drevesiny i tselliulozy. [Laboratory work on the chemistry of wood and cellulose]. Moscow, 1991, 320 p. (in Russ.).

25. Marchessault R.H. Pure Appl. Chem., 1962, vol. 5, no. 1-2, pp. 107-129.

26. Staehelin J., Hoigné J. Environ. Science Technol., 1982, vol. 16, no. 12, pp. 666-681.

27. Demin V.A., Shereshovets V.V., Monakov Iu.B. Uspekhi khimii, 1999, vol. 68, no. 11, pp. 1029-1050. (in Russ.).

28. Olkkonen C., Tylli Y., Forsskåhl I., Fuhrmann A., Hausalo T., Tamminen T., Hortling B., Janson J. Holzforschung, 2000, vol. 54, pp. 397-406.

29. Lemeune S., Jameel H., Chang H.-M., Kadla J.F. J. Applied Polymer Science, 2004, vol. 93, no. 3, pp. 1219-1223.

Received November 30, 2015

Revised December 25, 2015

\footnotetext{
* Corresponding author.
} 
